\title{
INTRA- AND INTER-SPECIFIC TRANSFER OF OVA BETWEEN EXPLANTED RAT AND MOUSE OVIDUCTS
}

\author{
D. G. WHITTINGHAM* \\ Division of Population Dynamics, \\ Johns Hopkins School of Hygiene and Public Health, Baltimore, Maryland
}

(Received 23rd July 1968)

\begin{abstract}
Summary. Intra- and inter-specific transfers of rat and mouse ova showed that native and foreign ova developed to the blastocyst stage within explanted oviducts of the rat and mouse.
\end{abstract}

Reports in the literature indicate that ova can develop in foreign oviductal environments in vivo at least to the blastocyst stage. Warwick \& Berry (1949) reciprocally transferred the cleavage stages of sheep and goats and obtained blastocysts in both instances. Averill, Adams \& Rowson (1955) found that the cleavage stages of the sheep developed to 8-day blastocysts when transferred to the rabbit oviduct. Briones \& Beatty (1954) were unsuccessful in their attempts to transfer cleavage stages between rat, mouse, guinea-pig and rabbit. However, Tarkowski (1962) reciprocally transferred the cleavage stages of the rat and mouse and obtained development to the blastocyst stage.

Reciprocal and non-reciprocal transfer of ova to explanted ampullae of the rat and mouse have been investigated to determine whether: (1) rat ova will develop in organ culture since they are somewhat refractory to the in vitro methods of culture used so successfully in the mouse (Brinster, 1963); and (2) the oviductal environment of the explanted ampullae from either species will support growth of foreign ova.

Methods of preparation and culture of mouse oviducts and the collection of zygotes have been described elsewhere (Whittingham, 1967, 1968a). Immature female albino rats, 26 to 28 days old, were injected intraperitoneally with 30 i.u. of PMSG followed $48 \mathrm{hr}$ later by 10 i.u. of HCG. After the second injection, the vagina was opened and the rats placed with proven males. The following morning they were checked for mating by examining the vaginal smears for spermatozoa. Fertilized 1-cell ova were obtained from successfully mated females and ampullae were removed from unmated animals, flushed with culture medium (Whittingham, 1968a) and placed in organ culture. The ampullar region of the oviduct was cultured since it has been shown previously that this region, but not the isthmus, supports development of mouse zygotes in organ culture (Whittingham, 1968a).

* Present address: Department of Veterinary Physiology, University of Sydney, Sydney, N.S.W. 2006, Australia. 
In the first series of experiments rat and mouse zygotes were reciprocally and non-reciprocally transferred to explanted ampullae (twelve ova/ampulla). Organ cultures containing mouse zygotes were cultured for $96 \mathrm{hr}$ and those containing rat ova for $120 \mathrm{hr}$ since rat zygotes reached the blastocyst stage in vivo approximately $24 \mathrm{hr}$ later than mouse zygotes. The results are summarized in Table 1. The data were subjected to $\chi^{2}$ analyses using Yates correction for continuity. The intra-specific transfer of mouse zygotes was significantly different from the other three combinations $(P<0 \cdot 001)$. Comparisons of the differences between the combinations of rat ova to mouse ampulla and mouse ampulla to rat ampulla were not significant. The combination of rat ova into rat ampullae was not very successful, only five ova from 141 ova recovered had reached the morula stage. The lower response in the number of mouse ova developing in the rat ampulla $(31.0 \%$ blastocysts and morulae) may be due either to the foreign environment of the rat ampulla or to the poor maintenance of the rat ampulla in organ culture. The rat ampullae after 4 to 5 days in culture

TABLE 1

DEVELOPMENT OF INTRA- AND INTER-SPEGIFIC ZYGOTES WITHIN EXPLANTED AMPULLAE FROM THE RAT AND MOUSE

\begin{tabular}{l|c|c|c|c|c|c}
\hline Type of transfer & $\begin{array}{c}\text { No } \\
\text { ampullae } \\
\text { cultured }\end{array}$ & $\begin{array}{c}\text { Duration } \\
o f \\
\text { culture } \\
(\text { hr })\end{array}$ & $\begin{array}{c}\text { No. ova recovered/ } \\
\text { No. ova transferred }\end{array}$ & $\begin{array}{c}\text { No. } \\
\text { morulae }\end{array}$ & $\begin{array}{c}\text { No. } \\
\text { blastocysts }\end{array}$ & $\begin{array}{c}\% \\
\text { Morulae } \\
\text { and } \\
\text { blastocysts }\end{array}$ \\
\hline Mouse $\rightarrow$ Mouse & 10 & 96 & $114 / 120$ & 11 & 53 & $56 \cdot 1$ \\
Rat $\rightarrow$ Rat & 16 & 120 & $141 / 192$ & 5 & 0 & $3 \cdot 5$ \\
Rouse $\rightarrow$ Rat & 10 & 96 & $100 / 120$ & 13 & 18 & $31 \cdot 0$ \\
Mat $\rightarrow$ Mouse & 22 & 120 & $245 / 264$ & 11 & 45 & $22 \cdot 1$ \\
\hline
\end{tabular}

on a chemically defined medium (Ham's nutrient mixture F10; Ham, 1963) were very friable and starting to disintegrate. This was in contrast to the apparently healthy appearance of the mouse oviduct after 4 days in culture (Whittingham, 1967), although the mouse ampulla did become more fragile after 5 days in culture. Nevertheless the overall results demonstrate that both rat and mouse ova will develop in explanted ampullae of either species in organ culture.

A second series of experiments was designed to determine if 2-cell rat ova would develop better in organ culture than the zygote. Two-cell rat ova (twelve/ampulla) were transferred to ampullae of the rat or mouse explanted at Metoestrus I (Whittingham, 1968b). The ampullae were cultured for $96 \mathrm{hr}$ and then flushed. The results are presented in Table 2. The development of a few 2-cell rat ova (19\% blastocysts and morulae) within the rat ampulla suggests that the shorter period of culture is less detrimental to the ovum. Perhaps 2-cell rat ova are less susceptible to adverse changes in the oviductal environment arising from manipulation and organ culture. The development of 2-cell rat ova within the mouse ampullae (46.8\% blastocysts and morulae) would support this view. 
This is the first recorded report of the successful development of 1-and 2-cell rat ova to the blastocyst stage obtained by in vitro organ culture techniques used successfully to culture the mouse zygote (Biggers, Gwatkin \& Brinster, 1962; Whittingham, 1968a). Earlier attempts to cultivate the rat cleavage stages in a completely in vitro system have had limited success (Mark \& Long, 1912; Defrise, 1933; Washburn, 1951; Wrba, 1956).

Rat ova developed within explanted ampullae maintained on a completely chemically defined medium (Ham's F10). This medium did not support the early cleavage stages outside the oviduct. Therefore the ampulla region of the oviduct must have provided the essential nutritive and protective requirements for the developing rat embryo. The poor maintenance of the rat oviduct in culture may be improved by the addition of the serum to the medium and warrants further investigation.

TABLE 2

DEVELOPMENT OF 2-CELL RAT OVA AFTER TRANSFER TO EXPLANTED RAT AND MOUSE AMPULLAE

\begin{tabular}{|c|c|c|c|c|c|}
\hline $\begin{array}{l}\text { Type of } \\
\text { transfer }\end{array}$ & $\begin{array}{l}\text { No. ampullae } \\
\text { cultured }\end{array}$ & $\begin{array}{l}\text { No. ova recovered } / \\
\text { No. ova transferred }\end{array}$ & $\underset{\text { morulae }}{\text { No. }}$ & $\begin{array}{c}\text { No. } \\
\text { blastocysts }\end{array}$ & $\begin{array}{c}\% \text { Morulae } \\
\text { and blastocysts }\end{array}$ \\
\hline $\begin{array}{l}\text { Rat } \rightarrow \text { Rat } \\
\text { Rat } \rightarrow \text { Mouse }\end{array}$ & $\begin{array}{r}6 \\
11\end{array}$ & $\begin{array}{c}63 / 72 \\
111 / 132\end{array}$ & $\begin{array}{l}10 \\
14\end{array}$ & $\begin{array}{r}2 \\
38\end{array}$ & $\begin{array}{l}19 \cdot 0 \\
46 \cdot 8\end{array}$ \\
\hline
\end{tabular}

* Ampullae cultured for $96 \mathrm{hr}$.

The reciprocal transfers confirmed, in part, the in vivo findings of Tarkowski (1962). However, he did not transfer ova at the 1-cell stage but showed that later cleavage stages (2-cell, 4-cell and 8-cell ova) would develop to the blastocyst stage in the foreign oviduct.

The author is indebted to Dr J. D. Biggers for his supervision and guidance during this investigation. The work was supported by grants to Dr J. D. Biggers from the Population Council Inc. and the National Cancer Institute, U.S. Public Health Service (CA-06639). Part of the investigation was conducted at the University of Pennsylvania when the author was a recipient of a Pennsylvania Plan Scholarship. The work was completed at Johns Hopkins School of Hygiene and Public Health when the author was a recipient of a traineeship from the National Institute of Health (5-TO1 HD 109-02).

\section{REFERENCES}

Averill, R. L. W., Adams, C. E. \& Rowson, L. E. A. (1955) Transfer of mammalian ova between species. Nature, Lond. 176, 167.

Biggers, J. D., Gwatkin, R. B. L. \& Brinster, R. L. (1962) Development of mouse embryos in organ cultures of fallopian tubes on a chemically defined medium. Nature, Lond. 194, 747.

Brinster, R. L. (1963) A method for in vitro cultivation of mouse ova from two-cell to blastocyst. Expl Cell Res. 32, 205.

BRIONES, H. \& BEATTY, R. A. (1954) Inter-specific transfers of rodent eggs. F. exp. Zool. 125, 99.

Defrise, A. (1933) Some observations on living eggs and blastulae of the albino rat. Anat. Rec. 57, 239. 
HAM, R. G. (1963) An improved nutrient solution for diploid Chinese hamster and human cell lines. Expl Cell Res. 29, 515.

MARK, F. L. \& Long, J. A. (1912) Studies on early stages of development in rats and mice. Univ. Calif. Publs Zool. 9, 105.

TARKowski, A. K. (1962) Inter-specific transfers of eggs between rat and mouse. F. Embryol. exp. Morph. $10,476$.

WARWICK, B. L. \& BERRY, R. O. (1949) Inter-generic and intra-specific embryo transfers in sheep and goats. F. Hered. 40, 297.

WASHBURN, W. W. (1951) A study of the modifications in rat eggs observed in vitro and following tubal retension. Archs Biol., Paris, 62, 439.

Whittingham, D. G. (1967) Studies on the early preimplantational stages of mammalian development. Ph.D. thesis, University of London.

Whitringham, D. G. (1968a) Organ culture of the mouse oviduct. I. The development of the zygote under varying oviductal conditions. F. exp. Zool. (In press).

Whittingham, D. G. (1968b) Organ culture of the mouse oviduct. 2. The influence of the estrous cycle and ovarian hormones upon the development of the zygote. F. exp. Zool. (In press).

WRBA, H. (1956) Zum Verhalten des befruchteten Ratteneies in vitro. Naturwissenschaften, 43, 334. 